Keeping Balance

On Desert and Propriety 


\title{
PRACTICAL PHILOSOPHY
}

\author{
Herausgegeben von / Edited by \\ Herlinde Pauer-Studer $\bullet$ Neil Roughley \\ Peter Schaber $\bullet$ Ralf Stoecker
}

\section{Band 10 / Volume 10}

The aim of the series is to publish high-quality work that deals with questions in practical philosophy from a broadly analytic perspective. These include questions in meta-ethics, normative ethics and "applied" ethics, as well as in political philosophy, philosophy of law and the philosophy of action. Through the publication of work in both German and English the series aims

to facilitate discussion between

English- and Germanspeaking practical philosophers. 


\section{Diana Abad}

\section{Keeping Balance}

On Desert and Propriety

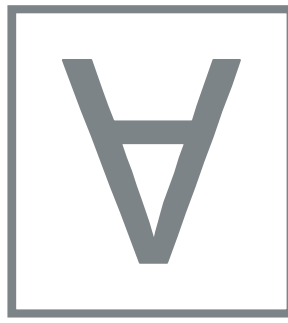

ontos

verlag 
Bibliographic information published by the Deutsche Nationalbibliothek

The Deutsche Nationalbibliothek lists this publication in the Deutsche Nationalbibliographie; detailed bibliographic data is available in the Internet at http://dnb.ddb.de

North and South America by

Transaction Books

Rutgers University

Piscataway, NJ 08854-8042

trans@transactionpub.com

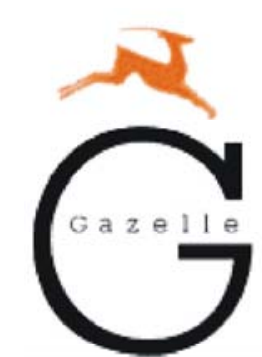

United Kingdom, Ire, Iceland, Turkey, Malta, Portugal by

Gazelle Books Services Limited

White Cross Mills

Hightown

LANCASTER, LA1 4XS

sales@gazellebooks.co.uk

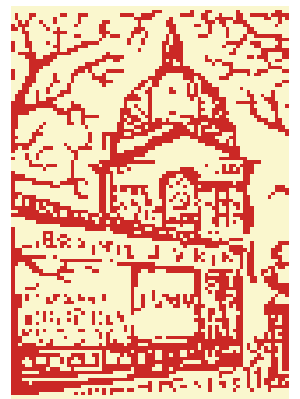

Livraison pour la France et la Belgique:

Librairie Philosophique J.Vrin

6 , place de la Sorbonne ; F-75005 PARIS

Tel. +33 (0)1 43540347 ; Fax +33 (0)1 43544818

www.vrin.fr

(C)2007 ontos verlag

P.O. Box 15 41, D-63133 Heusenstamm nr. Frankfurt

www.ontosverlag.com

ISBN 13: 978-3-938793-18-3

2007

No part of this book may be reproduced, stored in retrieval systems or transmitted in any form or by any means, electronic, mechanical, photocopying, microfilming, recording or otherwise without written permission from the Publisher, with the exception of any material supplied specifically for the purpose of being entered and executed on a computer system, for exclusive use of the purchaser of the work

Printed on acid-free paper ISO-Norm 970-6

This hardcover binding meets the International Library standard 